\title{
CAUSES OF DECLINING INTEREST OF STUDENTS TO EMPLOYMENT PHYSICAL EDUCATION AND
} SPORTS

\author{
Kondakov V.L., Kopeikina E.N., Balysheva N.V., Usatov A.N., Skrug D.A.
} National Research University Belgorod State University, Russia

\begin{abstract}
Annotation. Purpose: analysis of the main causes of the declining interest of students to the systematic physical training and sports. Material: The study involved 448 students (150 boys, 298 girls) conducted a questionnaire survey. Level of motor activity of students was determined using pedometers. Results: It was found that the transition of students in special medical groups inevitably entail a significant reduction in motor activity (it is almost 2 times lower than that of students of the main group of health). Notes the negative trend of increasing the number of students of both sexes who consume alcoholic beverages. Marked decrease of free time students because of the need to work. Conclusions: It is suggested to use a system of specific forms of organization of work and methods of influence that meet humanistic principles "to encourage, rather than compel." The function of such methods of influence should be to achieve the restructuring of the motivational sphere of students, the adequacy of their purpose activity.
\end{abstract}

Keywords: students, physical education, physical activity, personal orientation.

\section{Introduction}

Recent time great number of specialists in field of physical education raise question about need in increase of students' interest to physical culture and sports trainings [1, 3-7, 12-21]. As on to day program in discipline "Physical culture" for HEE envisages classes for $1^{\text {st }}-3^{\text {rd }}$ year students 2 times a week ( 2 academic hours every training). These classes shall be attended by all students, who have no medical counter indications, independent on the fact if they practice any kind of sports or physical culture in free time. However, analysis of physical culture academic records showed that about one third of students systematically miss planned trainings. With it, as it was cleared up as a result of questioning, 34.7\% of respondents noted absence of interest to physical trainings as the main reason of their missing. It is undoubted that two training a week of 90 minutes duration can not replenish deficit of students' motion functioning (MF), more over actually duration of some trainings often shortens. This shortening is caused by many objective reasons (moving to places of trainings, changing of cloth, fulfillment of sanitary-hygienic requirements after trainings and so on) and by some subjective reasons (unfavorable weather conditions, students' delays caused by giving back of manuals, delays in cloak room, visiting of WC and other).

At the same time demand of young organism in motion is 14-19 thousand steps a day or 1, 3-1, 8 hours a day.

Purpose, tasks of the work, material and methods of the research

The purpose of the work is to clear up the reasons of students' interest to systematic practicing of physical culture and sports decay.

Achievement of our purpose was ensured by solution of the following tasks:

1. Theoretical analysis and generalization of problem of students' motion functioning.

2. Study specific features of students' motion functioning in condition of their studying and in everyday conditions.

3. Determine main reasons, facilitating weakening of students' interest to systematic practicing of physical culture and sports.

In order to understand the reasons, facilitating interest's weakening, in 2013-2014 teachers of physical education department of SRU "BelSU" conducted anonymous questioning of $1^{\text {st }}-3^{\text {rd }}$ year students of different specialties. In questioning 448 students participated: 150 boys and 208 girls.

Solution of tasks, determined by purpose of our research, conditioned selection of methods of the research: theoretical analysis and generalization of literature sources, questioning, talks, statistical methods.

\section{Results of the research and discussion}

Numerous researches $[1,2,3,5,11]$, conducted in recent decade, witness that about $50 \%$ of students of Russian HEEs have health abnormalities. With every coming year increment of students, who, by their health condition, are allocated in special health groups (SHG), is registered, that is proved by our research (see fig.1). Quantity of students, for whom physical trainings are prohibited at all due to their health condition, significantly increased [1, 2, 8]. Actual scope of students' MF does not ensure full fledged physical development.

\footnotetext{
(c) Kondakov V.L., Kopeikina E.N., Balysheva N.V., Usatov A.N., Skrug D.A., 2015

http://dx.doi.org/10.15561/20755279.2015.0104
} 


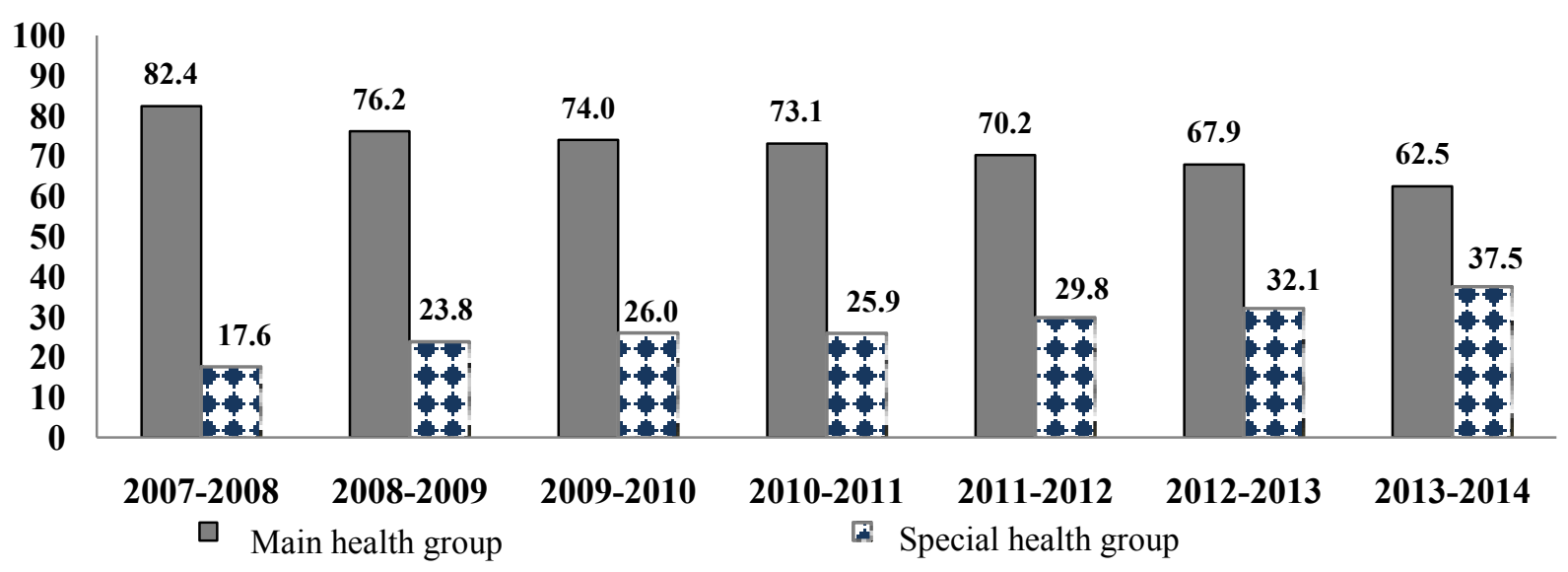

Fig.1. Correlation of students of main (MHG) special (SHG) groups in SRU “Bel SU” and

We analyzed level of students'from different health groups MF. We studied data of students' step-metering (main health group, special health group and students, released from trainings). These data are given in fig.2.

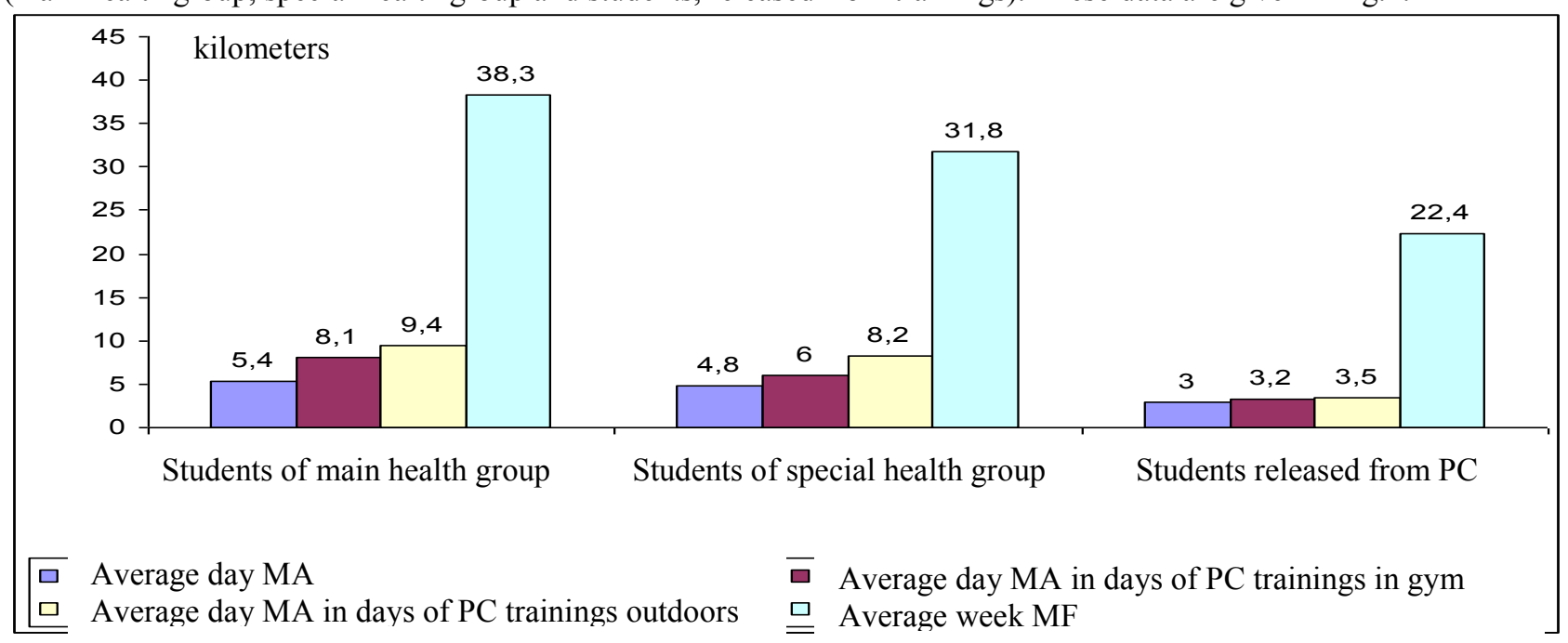

Fig.2. Motion functioning (MF) of students from different health groups (PC-physical culture)

Analysis of data witnesses that entering special health group and, more over, releasing from physical culture classes inevitably result in significant weakening of MF; with it in students, released from physical culture classes it is nearly 2 times lower than in main health group of students.

There appears certain contradiction: on the one hand MF is one of necessary components of healthy life style; it is a mean of health improvement; on the other hand young people, who have deviations in health, have indicators, reduced 2 times, while they especially need in improvement of health.

Contradiction is also in the fact that reduction of MF, being a result of health's weakening, simultaneously its reason. It is also proved by works of most of specialists [1, 10], as well as by our researches. For example quantity of students of Bielgorod HEEs, who additionally practice physical culture (in clubs or independently), reduces in proportion to increasing of students, who have health abnormalities of different heaviness (see fig.3). 


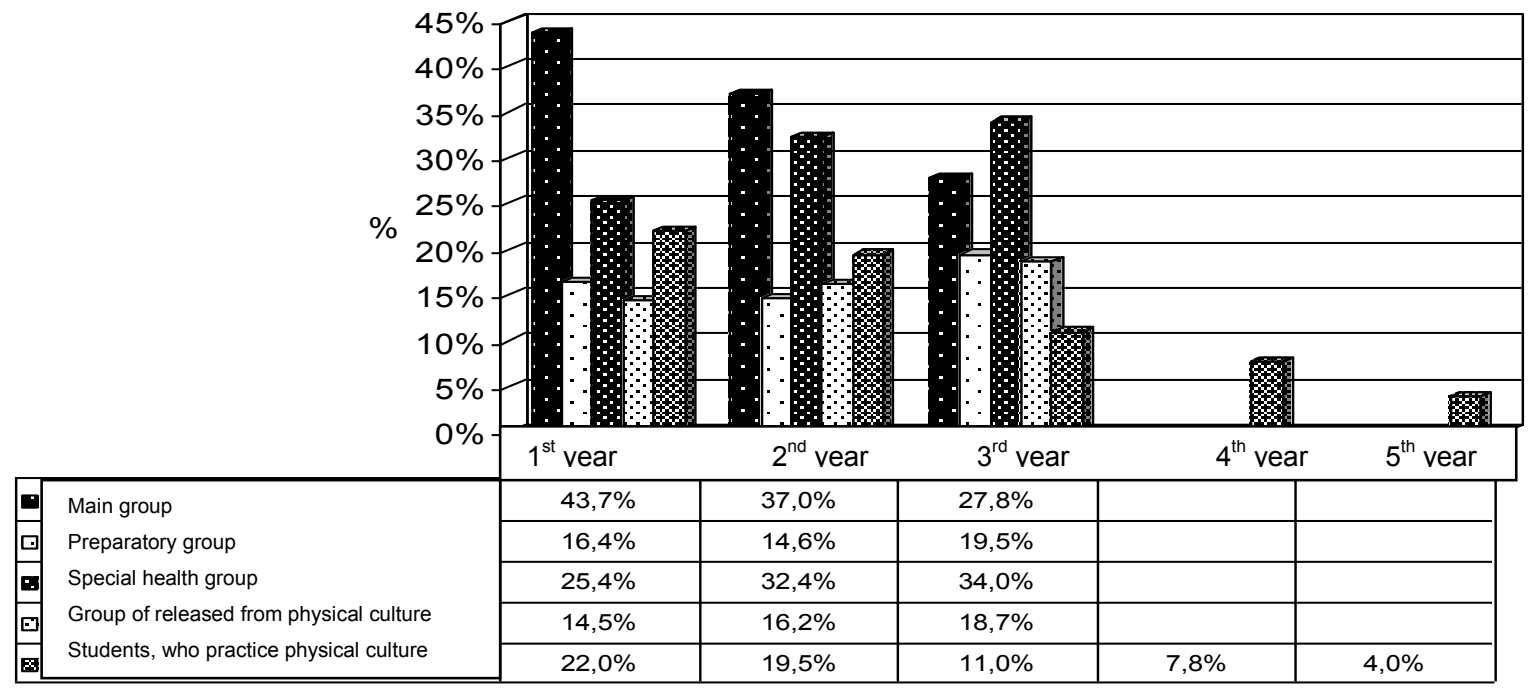

Fig.3. Dynamic of distribution of students by health groups and quantity of students, who practice physical culture additionally (PE-physical exercises, $P C$ - physical culture).

Analysis of students' answers to questions, which permit to asses their life style and determine factors, facilitating weakening of health, also cause trouble (see fig.4).

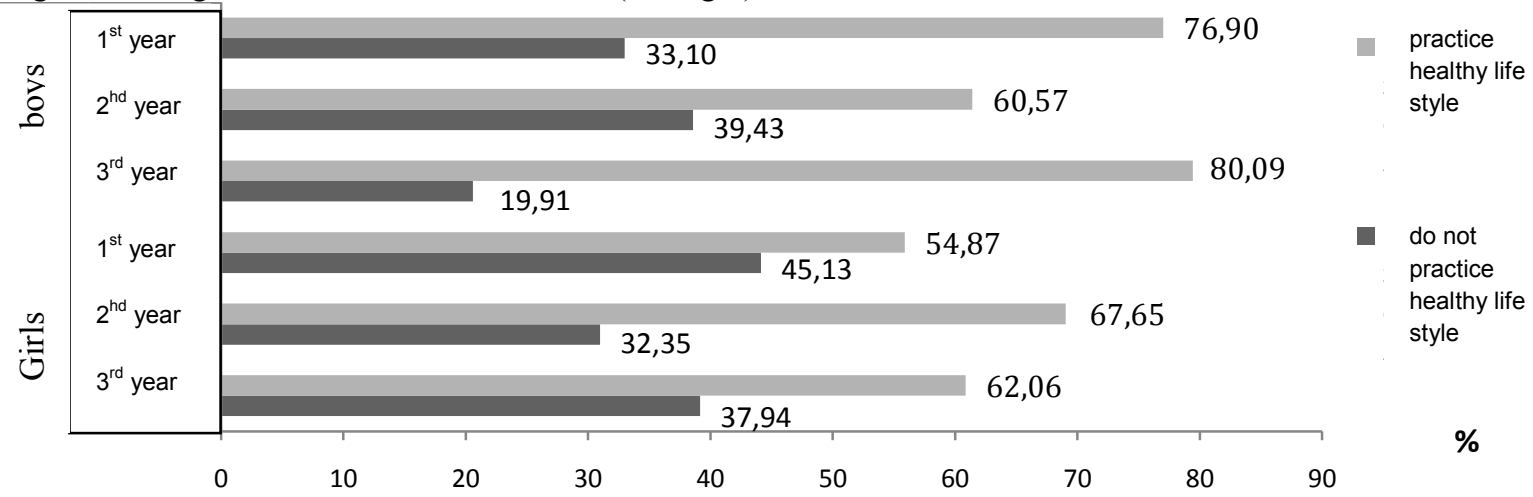

Fig.4. Self assessment of healthy life style by students of SRU "BelSU”

In spite of the fact that most of students declared their adherence to healthy life style we should note negative trend to increasing of quantity of students (boys and girls) who take alcohol (see fig.5).

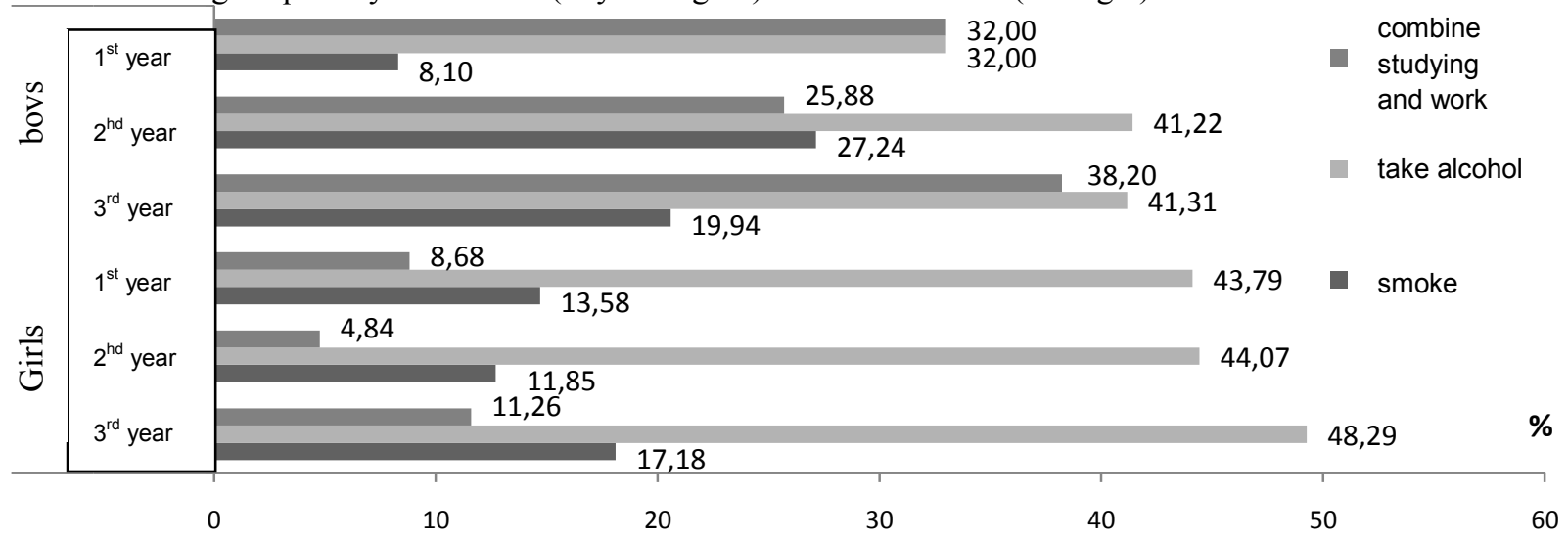

Fig.5. Negative factors in groups of SRU “BelSU” students

With it self-assessment of MF by students witnesses that their MF is not sufficient. For example most of boys characterize own MF as "above middle" and most of girls - as "middle" (see fig. 6). 
The research, conducted by us in a number of Bielgorod HEEs showed that actual students' MF is obviously lower than their self assessment. Harmful habits, reducing of MF and shortening of free time, connected with necessity to work, do not facilitate increase of interest to practicing of physical culture and sports.

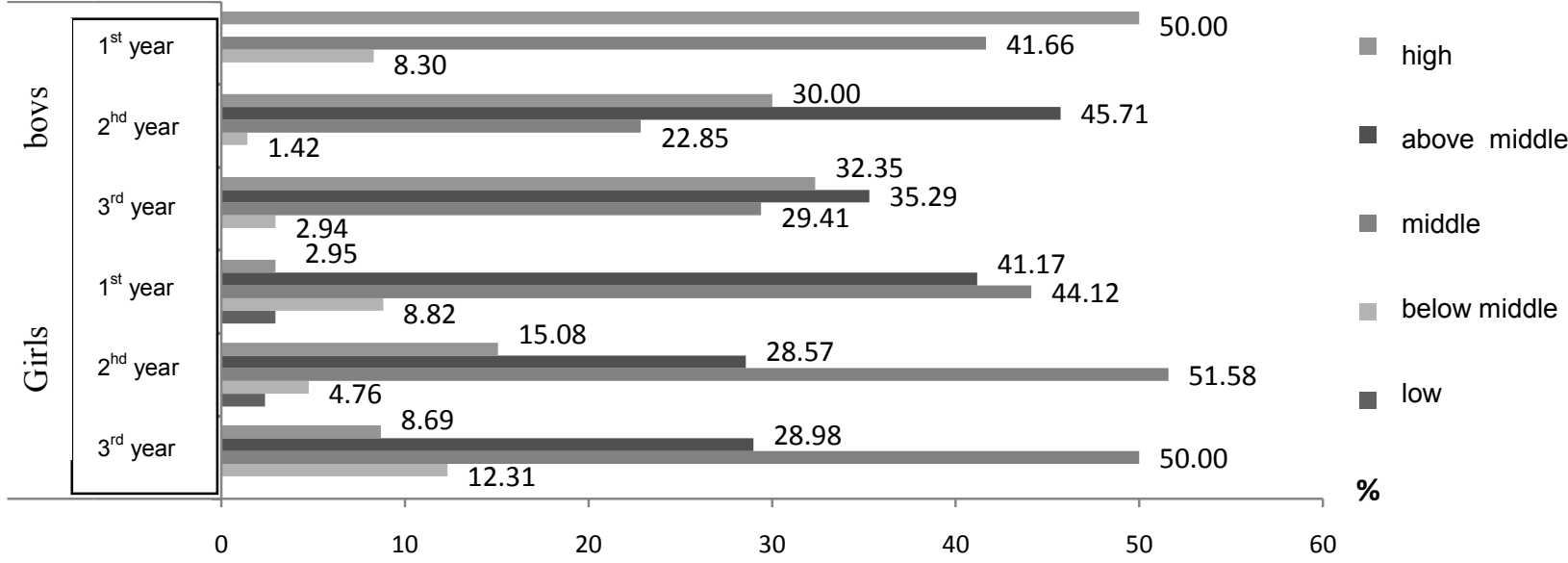

Fig.6. Self assessment of motion functioning of SRU “Bel SU” students

Analysis of formation of students' orientation on physical culture trainings permits to say that their orientation is, in the whole, poor. Among reasons of insufficient attention to own physical health, from 448 students $50 \%$ of boys and $54.5 \%$ of girls note absence of free time; indeed structure of free time to large extent influence on success of life targets', interests' and demands' formation. At present deficit of free time negatively influences on relation of youth to physical culture and sports' practicing, to taking them as desirable model of leisure.

It should be noted that $29 \%$ of girls and $4.5 \%$ of girls have practiced sports at all. Most of students do not practice physical culture besides compulsory classes, though by the data of questioning $28.5 \%$ of boys and $39 \%$ of girls point that just in their HEE there exist all conditions for physical culture and sports' practicing in convenient for them time. It was found that great majority of $1^{\text {st }}$ year students, i.e. senior pupils of yesterday $(75.8 \%)-$ attend physical culture classes because it is required by curriculum and only $9.4 \%$ attend these classes with wish.

In opinion of N.I. Ponomariov and V.M. Reisin [8] motives for physical culture practicing is the main condition of their effectiveness. Anonymous questioning of Bielgorod students showed that most of them have only one motive to receive credit, less part of students want to improve health; however, percentage of wishing to improve health is increasing with every coming year. Thus, we can conclude that first, most of students do not understand significance of physical culture for their health and future professional and life progress and second, - for most of them (students who attend trainings and who miss them) content of these classes is not interesting (see fig. 7).

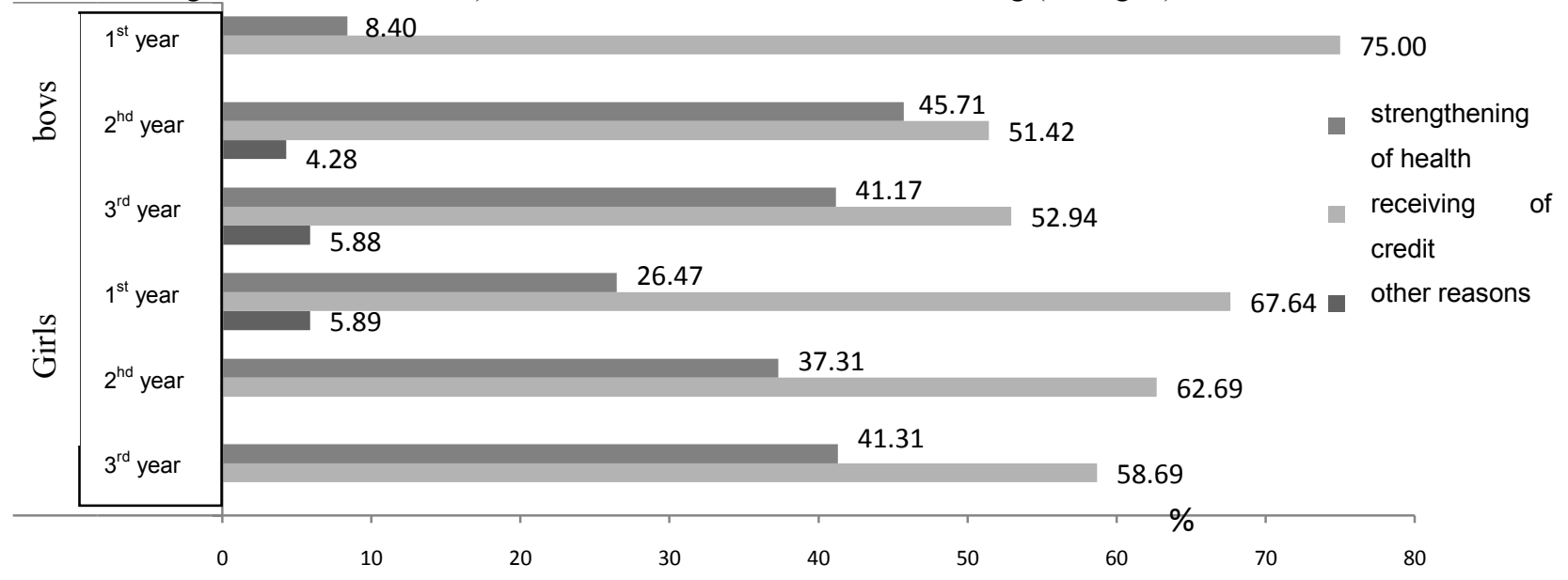

Fig. 7. Reasons of students' attendance of physical culture classes in SRW "BelSU”

The question what interest students manifested to physical culture at school, different years' students (boys and girls) was answered in somehow confusing way (see fig.8). 


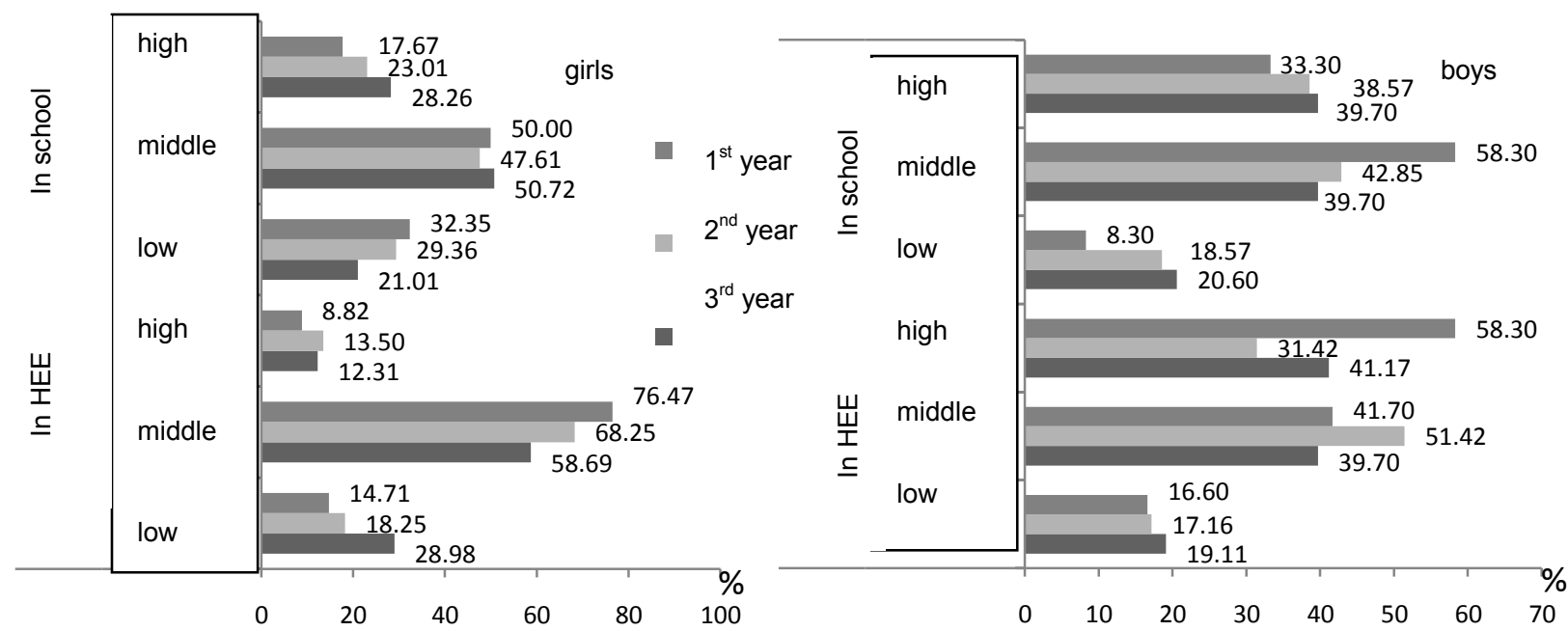

Fig.8. Interest of SRW "BelSU" students to physical culture at school and at HEE

At the first sight interest to physical culture should be equal and do not change with age. However, analysis of answers showed that with every year of studying at HEE students' interest to their physical classes at school increases. May be it is connected with some feeling of nostalgia, because it was interesting for them at school physical culture classes. Analysis of answers about interest to physical culture classes at HEE proves our assumption that with age both girls and boys loose interest to physical culture. For formation of positive emotions, increase of interest at physical culture trainings it is necessary: set clear, understood by students tasks; give, where it is necessary, scientific foundation of pedagogic and recommended methodic principles; avoid hackneyed patterns at classes, avoid monotony of used means; introduce novelty in exercises; use optimal loads and vary them; before new exercises give explanations to them; apply music (where it is possible) before exercises, in process of their fulfillment and in breaks between exercises as well as at the end of classes; consider commonality of trainees' purpose; regulate relations of trainees; form subgroups depending on their condition.

Reduction of students' MF is proved by comparison of results of answers to question about training in sport circles in school period and the, in period of study at HEE (see fig. 9). Girls stop practicing sports after school especially sharply. May be it is connected with deficit of free time, which they start to spend for preparation of home tasks, communication with new friends and so on.

Students' answers about kinds of sports, which were practiced by them in school period or are practicing at present time permitted to determine the most popular MF kinds. Most of boys marked out outdoor games. Girls also practiced often outdoor games in school period, but in student's life they start to pay attention to different aerobics.

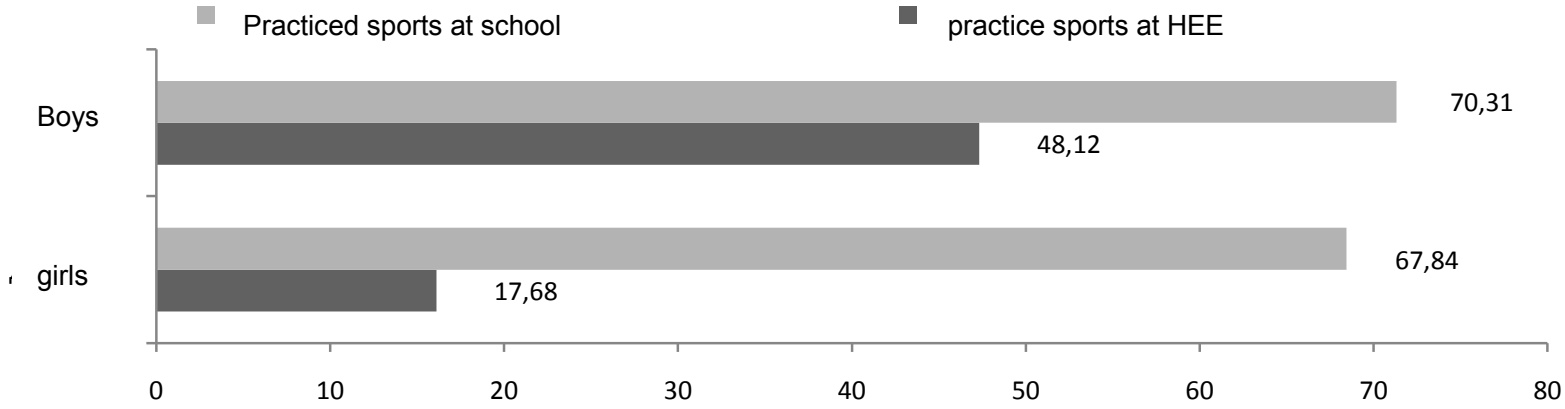

Fig.9. Attendance of sport circles by SRU "BelSU" students before entering HEE and at HEE

Students had different opinion in answers to question about changes in curriculum of "Physical culture" discipline. Most of students think it necessary to correct curriculum to some extent, the rest (minority) do not like any changes (see fig.10). In free time students can choose kinds of MF; different sport measures are organized for them at HEE sport sites. But, in spite of it, most of respondents answered that they do not participate in faculty's sport life. At senior years of studying quantity of students, participating in sport measures decreases. 


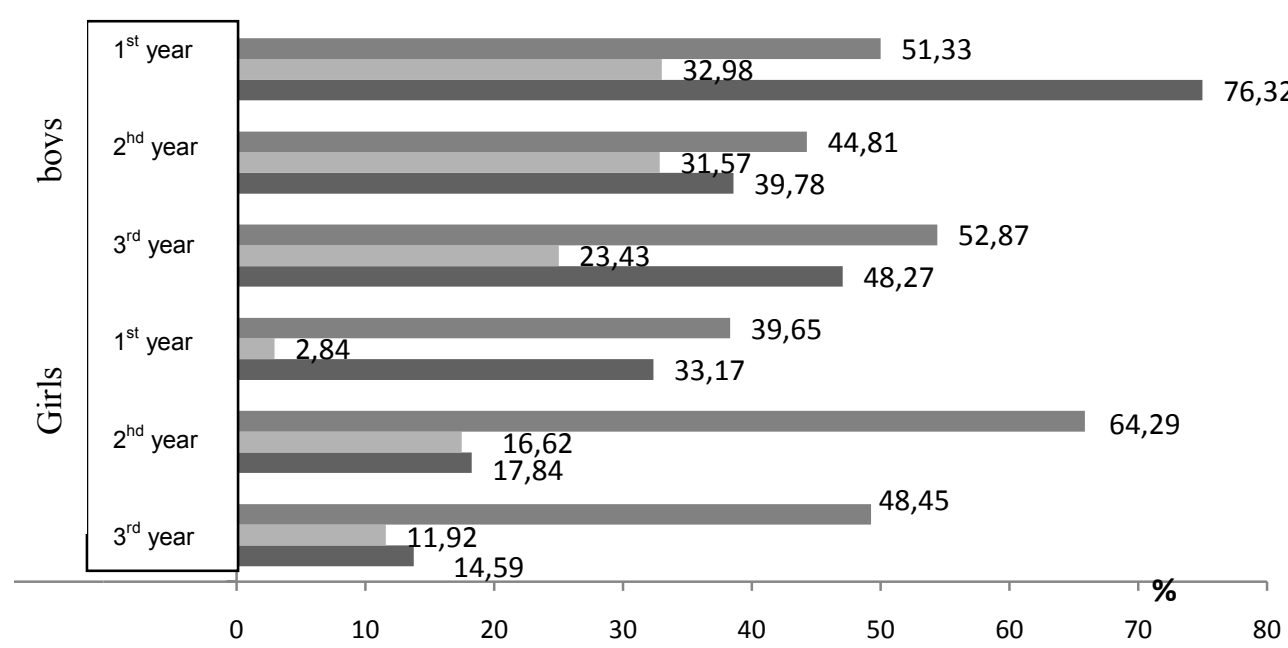

want to change content of physical culture class

participate in sport life of faculty

want to practice $\mathrm{PC}$ at $4^{\text {th }}$ and $5^{\text {th }}$ years of studying

Fig.10. Opinions about changes in physical culture and participation in faculty's sport life

There is negative trend in students' attitude possibility of physical culture classes at $4^{\text {th }}$ and $5^{\text {th }}$ years of studying. And if $1^{\text {st }}$ year students have obvious desire to continue physical culture trainings at $4^{\text {th }}$ and $5^{\text {th }}$ years, the, already $2^{\text {nd }}$ and $3^{\text {rd }}$ year students manifest weakening of such interest. Girls show even less interest to continuation of regular physical culture classes at $4^{\text {th }}$ and $5^{\text {th }}$ years of studying. Even among $1^{\text {st }}$ year girl students there is quite a few of such persons and further this quantity even became less.

It is obvious that intensification of students' MF is impossible without formation of their sincere interest to physical culture practicing and without their conscious desire to practice physical exercises additionally. Analysis of answers to question what exactly kinds of physical exercises they would like to practice is given in figure 11 .

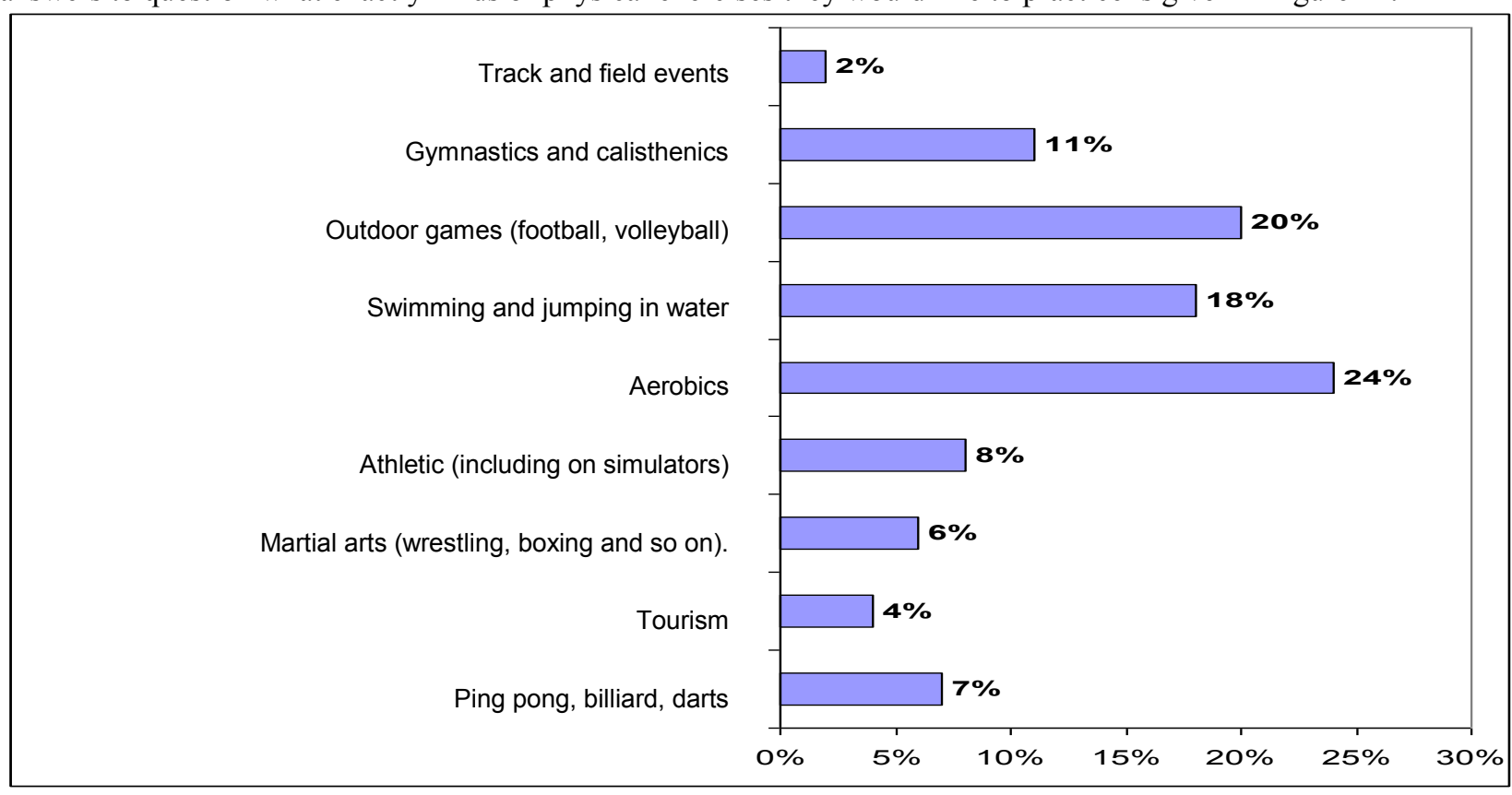

Fig.11. Kinds of physical exercises, preferred by students at physical culture classes

Significant part of the questioned (about 40\%) noted that they would like to practice interesting for them physical exercises additionally, out of academic time. Results of questioning are rather optimistic in the sense that they witness about presence of interest to MF and readiness to practice physical trainings of most of students. At the same time these results call for seeking of possibilities and ways of re-organization of physical education departments' work so that students could practice interesting for them physical exercises and for which they would be ready to find spare time.

\section{Conclusions:}

Thus, demand in increasing of students' MF is undoubted. Generalizing results of researches, conducted in Bielgorod HEEs we can conclude that MF is a necessary condition of students' health and progress. With it with years 
of studying students' MF reduces that, in its turn, results in worsening of their health and academic progress. Quantity of MF depends, first of all, on presence (or absence) of additional physical culture trainings and secondly, on group of health, in which student practice physical culture. One of reason of students' low MF is that physical culture trainings are not interesting for them and as a result about one third of students regularly miss them. Most of students do not loose interest to MF, but they would like to practice interesting for them physical exercises. The most interesting are aerobics, outdoor games, swimming. About $40 \%$ of students are ready to practice interesting for them physical exercises additionally.

Analysis of MF of SRU "BelSU" students showed that, on the one hand, it is necessary component of healthy life style, mean of health strengthening and, on the other hand, MF of young people with health abnormalities is lower nearly 2 times. This contradiction is amplified also by the fact that weakening of MF, being a result of health's worsening, is simultaneously a reason of it. This conclusion is proved by conducted by us researches, which show that main health group's students, who practice physical culture additionally, have the least percentage of morbidity. The second place is engaged by main group students, who attend only academic classes of physical culture. However, in spite of good indicators of educational functioning they have rather high percentage of catarrhal diseases. It also witnesses about prevailing significance of health in successful mastering of HEE curriculum.

All above said witnesses about demand in serious measures on cultivation of students' interest to different kinds of MF, on formation of personality's orientation on physical culture practicing and, in the whole, formation of their motivation for healthy life style.

In modern situation it is important to re understand content, methods and techniques of personality's orientation on the base of personality-active approach with pedagogic researches, analysis of subjective factors in the center. Especially troubling is absence of students' positive motivation for practicing of physical culture and sports.

It should also be noted that physical culture classes will be more effective if students realize purposes of physical culture and personal value of such trainings. That is why it is necessary to seek such methods of physical culture classes' organization, means of influence, which could more effectively ensure formation of positive personality's orientation on physical culture trainings.

In this conditions application of only traditional methods and means of influence, which often are in discordance between each other and weakly consider individual-typological features of students, are insufficiently promising. It would be more purposeful to use such holistic system of specific forms of trainings' organization and means of influence, which would meet humanistic principle "awakening instead of forcing" and, thus, increase interest of trainees to functioning, to which pedagogue orients them. Function of such means of influence shall ensure reconstruction of students' motivation sphere, adequately accepted by them purpose of functioning, resulted in positive orientation on it.

\section{References:}

1. Balysheva N.V., Bogoeva M.D., Kovaleva M.V., Kopejkina E.N., Rumba O.G. Obshchaia kharakteristika problemy deficita dvigatel'noj aktivnosti studentov s ogranichennymi vozmozhnostiami kardiorespiratornoj sistemy [General characteristics of the shortage of motor activity of students with disabilities cardiorespiratory system]. Kul'tura fizicheskaia i zdorov'e, 2013, vol.4, no.46, pp. 85-90. (in Russian)

2. Gorelov A.A., Rumba O.G., Kondakov V.L. Analiz pokazatelej zdorov'ia studentov special'noj medicinskoj gruppy [Analysis of indicators of health of students of special medical group]. Nauchnye problemy gumanitarnykh issledovanij. 2008, no.6, pp. 28-33. (in Russian)

3. Gorelov A.A., Kondakov V.L., Usatov A.N., To the question about the use of independent physical training in educational space of modern higher institute. Physical Education of Students, 2013, no.1, pp. 17-26. http://dx.doi.org/10.6084/m9.figshare.156351.

4. Gorelov A.A., Rumba O.G. , Kondakov V.L. Opyt ispol'zovaniia sredstv fizicheskoj kul'tury dlia povysheniia umstvennoj i fizicheskoj rabotosposobnosti, snizheniia nervno-emocional'nogo napriazheniia studentov $s$ narusheniiami v sostoianii zdorov'ia [Experience in the use of means of physical training to improve mental and physical performance, reduction of neuro-emotional stress of students with disabilities in the state of health]. Nauchnye vedomosti Belgorodskogo Gosudarstvennogo Universiteta, 2010, vol.6(77), no.5, pp. 185-192. (in Russian)

5. Gorelov A.A., Kondakov V.L., Rumba O.G. Fizkul'turno-ozdorovitel'nye tekhnologii kak sredstvo kinezioterapii v obrazovatel'nom prostranstve vuza [Sport and health technology as a means of physiotherapy in the educational space of the university]. Physical Education of Students, 2012, no.6, pp. $47-51$. http://dx.doi.org/10.6084/m9.figshare.96568 (in Russian)

6. Kondakov V.L., Usatov A.N, Usatov V.N., Goverdovskaia E.V. O neobkhodimosti povysheniia dvigatel'noj aktivnosti studentov vuzov [On the need to increase motor activity of university students]. Kul'tura fizicheskaia $i$ zdorov'e, 2008, vol.5, no.19, pp. 55-60. (in Russian)

7. Kondakov V.V., Kopejkina E.N., Usatov A.N., Balysheva N.V. Otnoshenie studentov k zaniatiiam fizicheskoj kul'turoj i sportom v obrazovatel'nom prostranstve sovremennogo vuza [The ratio of students to physical culture and sports in the educational space of the modern university]. Ekonomicheskie $i$ gumanitarnye issledovaniia regionov, 2014, no.3, pp. 48-52. (in Russian)

8. Kondakov V.L. Sistemnye mekhanizmy konstruirovaniia fizkul'turno-ozdorovitel'nykh tekhnologij v obrazovatel'nom prostranstve sovremennogo vuza. Dokt.diss. [System design mechanisms of health and fitness 
technology in the educational space of the modern university. Dokt. Diss.]. Sankt Petersburg,, 2013, 521 p. (in Russian)

9. Kondakov V.L. Upravlenie formirovaniem napravlennosti lichnosti shkol'nika (na materiale fizicheskoj kul'tury). Kand.diss. [Management of formation of orientation of the individual student (based on the physical culture). Kand.diss.]. Belgorod, 2000, 190 p. (in Russian)

10. Ponomarev N.I., Rejzin V.M. O formirovanii potrebnosti cheloveka $v$ fizkul'turno-sportivnoj deiatel'nosti (teoreticheskij aspekt) [On the formation of the human need for physical culture and sports activities (theoretical aspect).] Teoriia i praktika fizicheskoj kul'tury, 1988, no.10, pp. 2-4. (in Russian)

11. Alekseev N., Kutergin N., Kulinichev A., Gorbatenko A. Integrated method development of general and special students stamina involved in the fight. Physical Education of Students. 2014, no.3, pp. 3-8. http://dx.doi.org/10.6084/m9.figshare.974476.

12. Edge K., Khamsi K. International school partnerships as a vehicle for global education: student perspectives. Asia Pacific Journal of Education. 2012, vol.32, no.4, pp. 455-472. http://dx.doi.org/10.1080/02188791.2012.739964.

13. Iermakova T.S. Peculiarities of forming health culture of pupils in Poland: historical aspect. Pedagogics, psychology, medical-biological problems of physical training and sports, 2014, vol.6, pp. 16-20. http://dx.doi.org/10.6084/m9.figshare.1004090

14. Harris J. Physical education teacher education students' knowledge, perceptions and experiences of promoting healthy, active lifestyles in secondary schools. Physical Education and Sport Pedagogy. 2014, vol.19, no.5, pp. 466-480. http://dx.doi.org/10.1080/17408989.2013.769506.

15. Hemphill S.A., Plenty S.M., Herrenkohl T.I., Toumbourou J.W., Catalano R.F. Student and school factors associated with school suspension: A multilevel analysis of students in Victoria, Australia and Washington State, United States. Children and Youth Services Review. 2014, no.3, pp. 187-194. http://dx.doi.org/10.1016/j.childyouth.2013.11.022.

16. Humphrey N., Lendrum A., Barlow A., Wigelsworth M., Squires G. Achievement for All: Improving psychosocial outcomes for students with special educational needs and disabilities. Research in Developmental Disabilities. 2013, vol.34, no.4, pp. 1210-1225. http://dx.doi.org/10.1016/j.ridd.2012.12.008.

17. Macleod G., Cebula K.R. Experiences of disabled students in initial teacher education. Cambridge Journal of Education. 2009, vol.39, no.4, pp. 457-472. http://dx.doi.org/10.1080/03057640903352465.

18. Maivorsdotter N., Lundvall S. Aesthetic experience as an aspect of embodied learning: stories from physical education student teachers. Sport, Education and Society. 2009, vol.14, no.3, pp. $265-279$. http://dx.doi.org/10.1080/13573320903037622.

19. Mercier K., Doolittle S. Assessing Student Achievement in Physical Education for Teacher Evaluation. Journal of Physical Education, Recreation \& Dance. 2013, vol.84, no.3, pp. 38-42. http://dx.doi.org/10.1080/07303084.2013.767721.

20. Oh H-K., Rizzo T.L., So H., Chung D-H., Park S-J., Lei Q. Preservice physical education teachers' attributes related to teaching a student labeled ADHD. Teaching and Teacher Education. 2010, vol.26, no.4, pp. 885-890. http://dx.doi.org/10.1016/j.tate.2009.10.027.

21. Prusik Krzysztof, Prusik Katarzyna, Kozina Zh.L., Iermakov S.S. Features of physical development, physical preparedness and functional state of boys and girls - students of Polish higher educational establishments. Physical Education of Students, 2013, vol.1, pp. 54-61. http://dx.doi.org/10.6084/m9.figshare.96415 
Kondakov V.L.: http://orcid.org/0000-0002-8094-0144; kondakov@bsu. edu.ru; National Research University Belgorod State University; Pobeda 85, Belgorod, 308015, Russia.

Kopeikina E.N.: http://orcid.org/0000-0002-6027-3495; kopeikina@ bsu.edu.ru; National Research University Belgorod State University; Pobeda 85, Belgorod, 308015, Russia.

Balysheva N.V.: http://orcid.org/0000-0003-3657-8448; balysheva@ bsu.edu.ru; National Research University Belgorod State University; Pobeda 85, Belgorod, 308015, Russia.

Usatov A.N.: http://orcid.org/0000-0002-9148-5060; usatov@bsu.edu. ru; National Research University Belgorod State University; Pobeda 85, Belgorod, 308015, Russia.

Skrug D.A.: http://orcid.org/0000-0002-9570-4961; skrug@bsu.edu. ru; National Research University Belgorod State University; Pobeda 85, Belgorod, 308015, Russia.

Cite this article as: Kondakov V.L., Kopeikina E.N., Balysheva N.V., Usatov A.N., Skrug D.A. Causes of declining interest of students to employment physical education and sports. Physical education of students, 2015, no.1, pp. 22-30. http://dx.doi. org/10.15561/20755279.2015.0104

The electronic version of this article is the complete one and can be found online at: http://www.sportpedu.org.ua/html/arhive-e.html

This is an Open Access article distributed under the terms of the Creative Commons Attribution License, which permits unrestricted use, distribution, and reproduction in any medium, provided the original work is properly cited (http:// creativecommons.org/licenses/by/3.0/deed.en)

Received: 27.11.2014

Accepted: 06.12.2014; Published: 30.12.2014 